\title{
Effects of External Ventricular Drainage on Serum Sodium Levels in Adult Neurosurgical Patients
}

\section{Erişkin Nöroşirurji Hastalarında Eksternal Ventriküler Drenajın Serum Sodyum Düzeyine Etkisi}

\section{Oğuz BARAN ${ }^{1}$, Rahşan KEMERDERE² id , Odhan YÜKSEL ${ }^{2}$ iD, Sima SAYYAHMELLi² id, Nazan AKKAYA² id , Taner TANRIVERDi ${ }^{2}$ id, Ali Metin KAFADAR ${ }^{2}$ id ${ }^{1}$ Clinic of Neurosurgery, İstanbul Research and Training Hospital, İstanbul, Turkey ${ }^{2}$ Department of Neurosurgery, İstanbul University Cerrahpaşa School of Medicine, İstanbul, Turkey}

\section{ABSTRACT}

Objective: Hyponatremia is a common electrolyte abnormality observed in neurosurgical practice. The purpose of this article is to report the preliminary findings on the relationship between hyponatremia and continuous external ventricular drainage in adult neurosurgical patients.

Methods: We retrospectively studied the mean serum sodium $\left(\mathrm{Na}^{+}\right)$levels of 67 patients (29 females, 38 males) who were operated for intracranial pathologies and underwent external ventricular drainage insertion to monitor and decrease the intracranial pressure. We correlated serum $\mathrm{Na}^{+}$levels with cerebrospinal fluid (CSF) drainage in three time periods (early, medium, and late).

Results: The mean duration of CSF drainage was $10 \pm 6.4$ days. Fifteen patients experienced hyponatremia during CSF drainage. Thirteen of them $(86.6 \%)$ had borderline hyponatremia. One patient with the diagnosis of pituitary macroadenoma and one with subarachnoid hemorrhage had the mean serum $\mathrm{Na}^{+}$level of $129 \mathrm{mmol} / \mathrm{L}$ during the medium period. There was no significant correlation between the mean serum $\mathrm{Na}^{+}$levels and the CSF drainage values in any of the periods.

Conclusion: Our findings showed no association between hyponatremia and continuous CSF drainage in adult patients, indicating that external ventricular drainage can be safely used except in certain intracranial pathologies that require cautious observation for low $\mathrm{Na}^{+}$levels.

Keywords: External ventricular drainage, hyponatremia, adult, cerebrospinal fluid, sodium

\section{öz}

Amaç: Hiponatremi; erişkin nöroşirurji hastalarında sık görülen elektrolit bozukluklarından birisidir. Çalışmamızın amacı, eksternal ventriküler drenajla BOS kaybı ile serum sodyum düzeyi arasındaki ilişkiyi ortaya koymaktır.

Yöntemler: Çalışmada intrakranial patolojiler nedeniyle opere edilmiş ve eksternal ventriküler drenaj takılmış 67 hastanın (29 kadın, 38 erkek) serum sodyum düzeyleri retrospektif olarak çalışılmıştır. Hastaların serum sodyum düzeyleri; erken, orta ve geç dönem olmak üzere 3 farklı zaman dilimine ayrılmıştır.

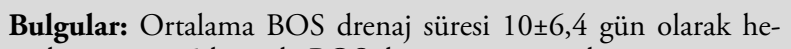
saplanmıştır. 15 hastada BOS drenajı süresince hiponatremi gelişmiştir. Bu hastaların 13'ünde $(\% 86,6)$ cerrahi öncesi sınırda hiponatremi bulunmaktaydı. Hipofiz makroadenomu olan bir hasta ile subaraknoid kanama tanısı ile takip edilen bir hastanın serum sodyumu postoperatif 3-7. günler arasında ortalama 129 $\mathrm{mmol} / \mathrm{L}$ olarak hesaplanmıştır. BOS drenajı ile serum sodyum düzeyi arasında postoperative erken, orta veya geç dönemde anlamlı ilişki saptanmamıştır.

Sonuç: BOS drenajı ile hiponatremi arasından anlamlı bir farklılık saptanmamış olması nedeniyle; EVD, hiponatremi yaratabilecek intrakranial patolojiler haricinde erişkin nöroşirurji hastalarında güvenle kullanılabilir.

Anahtar kelimeler: Eksternal ventrikuler drenaj, hiponatremi, erişkin, beyin omurilik sıvısı, sodyum

\section{Introduction}

Hyponatremia is a frequent cause of clinical alterations in neurosurgical patients. It may be due to the use of medications (e.g., carbamazepine and thiazides), syndrome of inappropriate antidiuretic hormone secretion (SIADH), hypocortisolism, polydipsia, or cerebral salt wasting, which are commonly seen in neuro-intensive care units (1-4). Clinical consequences of hyponatremia due to cerebral edema in the presence of hypoosmolality vary between mild symptoms, such as nausea and vomiting, and serious adverse effects including convulsions, coma, and even death $(5,6)$. Since neurosurgical patients are more vulnerable to the effects of cerebral edema owing to compromised osmoregulation, clinical results of severe hyponatremia can be devastating. In neurosurgical practice, low levels of sodium $\left(\mathrm{Na}^{+}\right)$are often observed in patients with subarachnoid hemorrhage $(\mathrm{SAH})$, pituitary adenomas, intracerebral space-occupying lesions, and brain injury

Cite this article as: Baran 0, Kemerdere R, Yüksel O, Sayyahmelli S, Akkaya N, Tanrıverdi T, Kafadar AM. Effects of External Ventricular Drainage on Serum Sodium Levels in Adult Neurosurgical Patients. Bezmialem Science 2018; 6: 84-8. 
(7-9). Intracranial pathologies leading to cerebrospinal fluid (CSF) circulation problems benefit from acute external ventricular drainage (EVD) for both intracranial pressure (ICP) monitoring and CSF drainage for pressure relief. Continuous EVD has certain complications, such as infection, technical obstructions, and recurrent hemorrhages, especially in $\mathrm{SAH}$ patients (10). In the current neurosurgical literature, there are sufficient data regarding the effects of continuous CSF drainage on serum $\mathrm{Na}^{+}$levels in children (11-15), but to the best of our knowledge, no report has been published regarding the same in case of adults.

In the present study, we aimed to analyze the relationship between hyponatremia and controlled CSF drainage in adult patients with various intracranial pathologies, and in the light of the findings, we wanted to research if CSF drainage induces hyponatremia or not. We evaluated whether long-term EVD has adverse effects on serum $\mathrm{Na}^{+}$levels and discussed the validity of this technique in the light of research results, patient characteristics, and scarce data published in the current literature.

\section{Methods}

Sixty-seven patients ( 29 female, 38 male) who were operated for various intracranial pathologies between 2014 and 2015 at the Istanbul University, Cerrahpasa Medical Faculty, Department of Neurosurgery and Istanbul Research and Training Hospital, Department of Neurosurgery, were included in this preliminary study. The study was performed with patients $\geq 17$ years of age with various intracranial pathologies that increased ICP levels and applied EVD. Patients $>17$ years and those with SIADH were excluded from this study. External ventricular drainage was used to monitor and decrease high ICP in all cases. The pressure of the EVD system was set at the level of external auditory meatus to maintain the ICP level of $\leq 15 \mathrm{mmHg}$. CFS drainage was controlled according to the ICP levels in patients with subarachnoid hemorrhage, whereas continuous drainage was performed in other cases. Drainage systems were changed every 10 days in cases with long-term follow-up to decrease the risk of infection. Patients with iatrogenic infection or meningitis and with serious systemic diseases (e.g., cardiac or renal disorders) were excluded from the study.

The information on the daily measurements of CSF drainage and electrolyte levels was gathered from the patient records. The medical treatments that can affect blood electrolyte levels were noted. The follow-up of external ventricular drainage was divided into three periods: the early period, $0-72$ hours; the medium period, 3-7 days; and the late period, $>7$ days. The basal serum levels of $\mathrm{Na}^{+}$before EVD placement and the mean $\mathrm{Na}^{+}$levels during the early, medium, and late periods were also recorded. Hyponatremia was defined as the serum $\mathrm{Na}^{+}$concentration $<136 \mathrm{mmol} / \mathrm{L}$. For the treatment of hyponatremia, isotonic and isolyte solutions were given for patients with $\mathrm{Na}^{+}$levels $<136 \mathrm{mmol} / \mathrm{L}$, and $3 \% \mathrm{NaCl}$ solution for those with the levels $<130 \mathrm{mmol} / \mathrm{L}$. The patients who had pre-existing hyponatremia before EVD and who also experienced decreased serum $\mathrm{Na}^{+}$levels during the CSF drainage $(n=7)$ were excluded from the analysis of hyponatremia related to EVD. Informed consents were signed by the relatives of the patients.

\section{Statistical analyses}

Statistical analyses were done using the IBM Statistical Package for the Social Sciences version 22 (IBM SPSS Statistics; Armonk, NY, USA). Bivariate correlation analyses were performed, and the Pearson's correlation coefficient was used to show the relationship between CSF drainage and serum $\mathrm{Na}^{+}$ levels in each time period.

\section{Ethics statement}

Application to ethics committee has been made for this study, and the study has been exempted from approval since it was a retrospective data analysis. The study was conducted in accordance with the Declaration of Helsinki.

\section{Results}

The patients ranged between 17 and 88 years of age (mean: $50.8 \pm 19.3$ years). The mean duration of CSF drainage was $10 \pm 6.4$ (range: $3-29$; median: 9) days. The mean values of daily CSF drainage were 214.3, 186.1, and $180.8 \mathrm{ml}$ for the early, medium, and late periods, respectively. Basal serum $\mathrm{Na}^{+}$ levels before the insertion of the EVD system ranged between 131 and $146 \mathrm{mmol} / \mathrm{L}$ (mean: 139.6 \pm 3.4 ).

Hyponatremia was observed in 11 patients before the insertion of EVD. Four of them showed no abnormalities during CSF drainage, whereas hyponatremia (mean $\mathrm{Na}^{+}: 135 \mathrm{mmol} / \mathrm{L}$ ) persisted in two patients only during the early period, in one only during the medium period (mean $\mathrm{Na}^{+}: 134 \mathrm{mmol} / \mathrm{L}$ ), and in one patient during both the early and medium periods (mean $\mathrm{Na}^{+}: 135 \mathrm{mmol} / \mathrm{L}$ for both periods), but it returned to normal in the rest of their follow-up. On the other hand, hyponatremia continued during all drainage periods in three patients who already had low $\mathrm{Na}^{+}$levels before the procedure (mean $\mathrm{Na}^{+}: 133 \mathrm{mmol} / \mathrm{L}, 131.6 \mathrm{mmol} / \mathrm{L}$, and $132 \mathrm{mmol} / \mathrm{L}$ for early, medium, and late periods, respectively).

A total of 15 patients (25\%) experienced hyponatremia following the placement of EVD (Table 1). The rate of hyponatremia during drainage was $11.6 \%, 19.6 \%$, and $17.1 \%$ for the early, medium, and late periods, respectively; it was noted in seven patients in the early period of CSF drainage. Of these, hyponatremia persisted in the medium period in five cases, during all drainage periods in one patient, and was noticed after 1 week (the late period) in the other. Five of these patients with hyponatremia had the diagnosis of intracranial aneurysm, two had frontobasal tumors (e.g., meningioma and pituitary adenoma), four had intraventricular hematoma, whereas one patient had intraaxial tumor, one had meningitis, and one had posterior fossa hematoma. When we compared the CSF drainage and the mean $\mathrm{Na}^{+}$levels in the early period, no significant correlation was observed $(p>0.05)$. 
Table 1. Characteristics of patients with hyponatremia

\begin{tabular}{|c|c|c|c|c|c|c|c|c|c|c|}
\hline \multirow[b]{2}{*}{ No } & \multirow[b]{2}{*}{ Age } & \multirow[b]{2}{*}{ Sex } & \multirow[b]{2}{*}{ Diagnosis } & \multirow[b]{2}{*}{$\begin{array}{c}\text { EVD } \\
\text { Duration }\end{array}$} & \multicolumn{2}{|c|}{ Early period } & \multicolumn{2}{|c|}{ Medium period } & \multicolumn{2}{|c|}{ Late period } \\
\hline & & & & & $\begin{array}{l}\text { CSFd } \\
\text { (cc/d) }\end{array}$ & $\begin{array}{c}\mathrm{Na} \\
(\mathrm{mmol} / \mathrm{l})\end{array}$ & $\begin{array}{l}\text { CSFd } \\
\text { (cc/d) }\end{array}$ & $\begin{array}{l}\text { NaCSFd } \\
(\mathrm{mmol} / \mathrm{l})\end{array}$ & $\begin{array}{l}\text { CSFd } \\
\text { (cc/d) }\end{array}$ & $\begin{array}{c}\mathrm{Na} \\
(\mathrm{mmol} / \mathrm{l})\end{array}$ \\
\hline 1 & 30 & $\mathrm{~F}$ & Aneurysm (BA), SAH & 9 & 195 & 135 & 122.5 & 136 & 110 & 133 \\
\hline 2 & 24 & $\mathrm{~F}$ & Glial tumour & 7 & 197.6 & 137 & 265 & 134 & - & - \\
\hline 3 & 24 & M & Pituitary macroadenoma & 7 & 176.6 & 134 & 90 & 129 & - & - \\
\hline 4 & 52 & $\mathrm{~F}$ & Frontobasal meningioma & 20 & 336.6 & 139 & 242 & 136 & 118.4 & 131 \\
\hline 5 & 55 & M & Meningitis & 26 & 240 & 138 & 196.8 & 138 & 146.4 & 135 \\
\hline 6 & 62 & $\mathrm{~F}$ & IVH & 13 & 216 & 136 & 184.8 & 135 & 213.6 & 136 \\
\hline 7 & 69 & $\mathrm{~F}$ & Aneurysm (MCA), SAH & 4 & 132 & 136 & 96 & 135 & - & - \\
\hline 8 & 69 & $\mathrm{~F}$ & Posterior fossa hematoma & 9 & 192 & 133 & 158.4 & 135 & 84 & 136 \\
\hline 9 & 73 & $\mathrm{~F}$ & IVH & 9 & 228 & 134 & 256.8 & 135 & 206.4 & 138 \\
\hline 10 & 54 & $\mathrm{~F}$ & Aneurysm (ACoA), SAH & 9 & 206.4 & 131 & 185.7 & 133 & 187.4 & 132 \\
\hline 11 & 79 & M & IVH & 9 & 283.6 & 138 & 256.3 & 134 & 259.4 & 136 \\
\hline 12 & 74 & M & IVH & 12 & 249.6 & 132 & 259.2 & 134 & 196.8 & 136 \\
\hline 13 & 46 & M & Aneurysm (ACoA), SAH & 10 & 163.2 & 137 & 174.6 & 134 & 134.4 & 135 \\
\hline 14 & 50 & $\mathrm{~F}$ & Aneurysm (ACoA), SAH & 16 & 196.3 & 134 & 177.6 & 129 & 156 & 136 \\
\hline 15 & 28 & $\mathrm{~F}$ & Meningitis & 17 & 235.2 & 138 & 225.6 & 136 & 211.2 & 135 \\
\hline
\end{tabular}

Four patients suffered borderline hyponatremia $\left(\mathrm{Na}^{+}: 134-\right.$ $135 \mathrm{mmol} / \mathrm{L})$ only in the medium period and three $\left(\mathrm{Na}^{+}\right.$: $131-135 \mathrm{mmol} / \mathrm{L}$ ) only in the late period. In one patient with SAH and aneurysm of anterior communicating artery, the mean serum $\mathrm{Na}^{+}$level decreased to $134 \mathrm{mmol} / \mathrm{L}$ three days after EVD insertion and maintained at the mean level of $135 \mathrm{mmol} / \mathrm{L}$ in the late period. There was no statistically significant correlation between the mean $\mathrm{Na}^{+}$levels and the CSF drainage values in the medium and late periods $(\mathrm{p}>0.05)$. The frequencies of the mean serum $\mathrm{Na}^{+}$levels in the patients with EVD system during the early, medium, and late periods are shown in Figure 1.

A total of $86 \%$ of the patients with hyponatremia $(n=13)$ had serum $\mathrm{Na}^{+}$levels between 135 and $130 \mathrm{mmol} / \mathrm{L}$. One patient with the diagnosis of pituitary macroadenoma (nonsecretory) had a reduced mean serum $\mathrm{Na}^{+}$level $(129 \mathrm{mmol} / \mathrm{L})$ three days after the EVD procedure. An increased urine output was noted in this patient, and his urine $\mathrm{Na}^{+}$concentration was 256 (Normal: $40-220) \mathrm{mEq} / \mathrm{L}$ and urine osmolality was 1250 (Normal: $50-1200) \mathrm{mOsm} / \mathrm{kg}$ in the 24-hour urine collection. Another patient with SAH due to a rupture of the middle cerebral artery aneurysm suffered from hyponatremia as low as $129 \mathrm{mmol} / \mathrm{L}$ during the medium period, but recovered to normal with hypertonic solutions.

Besides low serum $\mathrm{Na}^{+}$concentrations, hypernatremia $\left(\mathrm{Na}^{+}>145 \mathrm{mmol} / \mathrm{L}\right)$, although rarely, was also observed when draining CSF. A total of $9 \%(n=6)$ of the patients had hypernatremia during the early period, while it occurred during the medium and late periods in $1.5 \%$ and $2.5 \%$ of the patients, respectively.

\section{Discussion}

In a retrospective study of intensive care patients, Funk et al. (16) classified their patients depending on the $\mathrm{Na}^{+}$levels as those with borderline hyponatremia (serum $\mathrm{Na}^{+}$: 130-135 $\mathrm{mEq} / \mathrm{L}$ ), mild hyponatremia (serum $\mathrm{Na}^{+}: 125-129 \mathrm{mEq} / \mathrm{L}$ ), and severe hyponatremia (serum $\left.\mathrm{Na}^{+}<125 \mathrm{mEq} / \mathrm{L}\right)$.

We want to discuss our findings by separating the patients into two groups: the hyponatremia and the non-hyponatremia group. A total of $25 \%$ (15 patients) of patients were in the hyponatremia group of our study. After this, we performed the second classification for the hyponatremia group; borderline, mild, and severe hyponatremia, as mentioned in the previous study (16). Accordingly, the rate of subclassification for hyponatremia group was $53.3 \%, 46.7 \%$, and $0 \%$, respectively. During CSF drainage in the borderline group, only two patients had the mean serum $\mathrm{Na}^{+}$level of $129 \mathrm{mmol} / \mathrm{L}$ between the third and the seventh day of the procedure. As overt symptoms such as seizure and obtundation are usually expected with much lower (i.e., $<115 \mathrm{mEq} / \mathrm{L}$ ) serum $\mathrm{Na}^{+}$levels (17), we did not observe serious neurological complications due to the decreased serum $\mathrm{Na}^{+}$levels. 


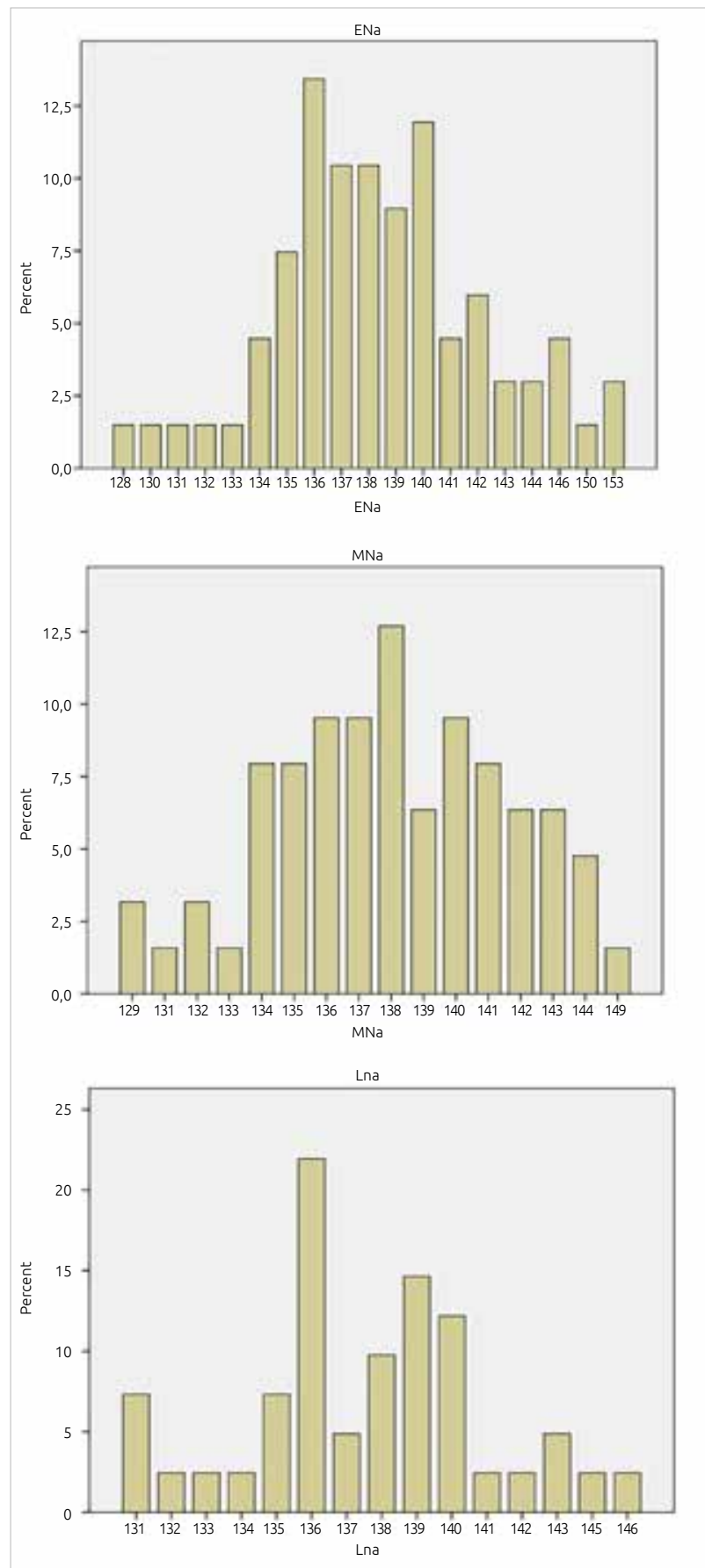

Figure 1 . The frequencies of mean serum sodium levels in the early, medium, and late periods

Our subjects in the study showed no significant correlation between hyponatremia and daily measurements of CSF drainage during the EVD follow-up periods. According to urine output and urine $\mathrm{Na}^{+}$and osmolality measurements, low serum $\mathrm{Na}^{+}$levels were attributed to cerebral salt wasting syndrome, which is frequently encountered after intracranial surgery, especially among SAH patients (18). The incidence of hyponatremia in SAH due to intracerebral aneurysm is reported to be $34 \%$ (8). In fact, five of the 11 aneurysm patients in our study had pre-existing, borderline hyponatremia before EVD insertion, and it was observed in
$83 \%$ of the remaining aneurysm cases during CSF drainage. Of note, none of our patients had severe hyponatremia. The most prominent $\mathrm{Na}^{+}$imbalance occurred in a patient with pituitary macroadenoma $\left(\mathrm{Na}^{+}: 129 \mathrm{mmol} / \mathrm{L}\right)$, which can be expected due to high prevalence of hyponatremia after transsphenoidal pituitary surgery (7). The hyponatremia observed in this case was ascribed to cerebral salt wasting due to surgery rather than EVD. Therefore, the hyponatremia successfully profited from the volume repletion therapy with hyperosmolar fluids.

CSF is a slightly hypertonic fluid relative to plasma, with a constant $\mathrm{Na}^{+}$concentration of approximately $150 \mathrm{mmol} / \mathrm{L}$ (19-21). During the CSF production by choroid plexus, $\mathrm{Na}^{+}$ ions are actively pumped across the epithelial surface by the $\mathrm{Na}^{+}, \mathrm{K}^{+}$ATPase, and other $\mathrm{Na}^{+}$co-transporters. The resultant osmotic gradient leads to the secondary active transport of chloride and water molecules (22). Therefore, excessive CSF loss by drainage is assumed to deplete total $\mathrm{Na}^{+}$and water composition of the body (14). The relationship between EVD and hyponatremia has generally been shown in pediatric cases with raised ICP and hydrocephalus, which demonstrates that over or uncontrolled drainage may cause severe dehydration and hyponatremia with life-threatening conditions in children. This seems to be associated with high susceptibility of infants to electrolyte imbalances due to disproportions between their body weight and body surface area (12). On contrary, the situation appears to be slightly different in adults. In the present study evaluating the effects of short, medium, and long-term CSF drainage on serum $\mathrm{Na}^{+}$levels, we could detect no significant correlation between those two parameters. Moreover, hyponatremia that was observed in 15 patients $(25 \%)$ was within reasonable limits, without leading to clinical derangements.

Serum electrolyte levels are influenced by many factors and systemic events as well. Our study seems to have limitations from this point of view, as it did not present the evaluation of volume status and analysis of urine $\mathrm{Na}^{+}$levels and osmolality for all patients. Nonetheless, we preferred to explain the details for specific cases as serum $\mathrm{Na}^{+}$concentrations were not dramatically affected, and we aimed to focus on the relationship between hyponatremia and CSF drainage, but not on the other factors related to this condition.

\section{Conclusion}

Although hyponatremia can be observed during the longterm EVD (>1 week) in adult patients with the intracranial surgical pathologies increasing ICP, it is not directly related to draining CSF. The cranial disease itself is more likely to be a risk factor contributing to hyponatremia. However, serum $\mathrm{Na}^{+}$concentrations need to be regularly measured in patients with EVD who have systemic disorders that make them vulnerable to electrolyte imbalances, as well as cranial pathologies such as SAH and pituitary adenoma. As no previous literature data have been found, we believe that our preliminary results 
will be useful for further investigations of specific neurosurgical cases focusing on detailed electrolyte changes in CSF loss.

Ethics Committee Approval: Authors declared that the research was conducted according to the principles of the World Medical Association Declaration of Helsinki "Ethical Principles for Medical Research Involving Human Subjects", (amended in October 2013).

Informed Consent: Written informed consent was obtained from patients' parents who participated in this study.

Peer-review: Externally peer-reviewed.

Author Contributions: Concept - T.T., R.K., O.Y.; Design - R.K., T.T.; Supervision - T.T., A.M.K.; Resources - N.A., S.S.; Materials O.B., N.A.; Data Collection and/or Processing-O.B., N.A.; Analysis and/or Interpretation - T.T., A.M.K., R.K.; Literature Search R.K., O.Y., O.B.; Writing Manuscript - R.K., O.B.; Critical Review - T.T., A.M.K., O.Y., S.S.; Other - S.S., N.A.

Conflict of Interest: No conflict of interest was declared by the authors.

Financial Disclosure: The authors declared that this study has received no financial support.

Etik Komite Onayı: Yazarlar çalışmanın World Medical Association Declaration of Helsinki "Ethical Principles for Medical Research Involving Human Subjects", (amended in October 2013) prensiplerine uygun olarak yapıldığını beyan etmişlerdir.

Hasta Onamı: Yazılı hasta onamı bu çalışmaya katılan hastaların ailesinden alınmıştır.

Hakem Değerlendirmesi: Dış bağımsız.

Yazar Katkıları: Fikir -T.T., R.K., O.Y.; Tasarım - R.K., T.T.; Denetleme - T.T., A.M.K.; Kaynaklar - N.A., S.S.; Malzemeler - O.B., N.A.; Veri Toplanması ve/veya İşlemesi - O.B., N.A.; Analiz ve/veya Yorum - T.T., A.M.K., R.K.; Literatür Taraması - R.K., O.Y., O.B.; Yazıyı Yazan - R.K., O.B.; Eleştirel İnceleme - T.T., A.M.K., O.Y., S.S.; Diğer - S.S., N.A.

Çıkar Çatışması: Yazarlar çıkar çatışması bildirmemişlerdir.

Finansal Destek: Yazarlar bu çalışma için finansal destek almadıklarını beyan etmişlerdir.

\section{References}

1. Peters JP, Welt LG, Sims EA, Orloff J, Needham J. A salt-wasting syndrome associated with cerebral disease. Trans Assoc Am Physicians 1950; 63: 57-64.

2. Schwartz WB, Bennett W, Curelop S, Bartter FC. A syndrome of renal sodium loss and hyponatremia probably resulting from inappropriate secretion of antidiuretic hormone. Am J Med 1957; 23: 529-42. [CrossRef]

3. Bhardwaj A. Neurological impact of vasopressin dysregulation and hyponatremia. Ann Neurol 2006; 59: 229-36. [CrossRef]

4. Silvani A, Gaviani P, Lamperti E, Botturi A, Ferrari D, Simonetti $\mathrm{G}$, et al. Metabolic, electrolytes disorders and trombo- embolic risk in malignant glioma patients. Neurol Sci 2011; 32: 229-31. [CrossRef]

5. Buffington MA, Abreo K. Hyponatremia: A Review. J Intensive Care Med 2016; 31: 223-36. [CrossRef]

6. Hew-Butler T, Ayus JC, Kipps C, Maughan RJ, Mettler S, Meeuwisse WH, et al. Statement of the Second International Exercise-Associated Hyponatremia Consensus Development Conference, New Zealand, 2007. Clin J Sport Med 2008; 18 : 111-21. [CrossRef]

7. Olson BR, Gumowski J, Rubino D, Oldfield EH. Pathophysiology of hyponatremia after transsphenoidal pituitary surgery. J Neurosurg 1997; 87: 499-507. [CrossRef]

8. Hasan D, Wijdicks EF, Vermeulen M. Hyponatremia is associated with cerebral ischemia in patients with aneurysmal subarachnoid hemorrhage. Ann Neurol 1990; 27: 106-8. [CrossRef]

9. Audibert G, Hoche J, Baumann A, Mertes PM. Water and electrolytes disorders after brain injury: mechanism and treatment. Ann Fr Anesth Reanim 2012; 31: 109-15. [CrossRef]

10. Bogdahn U, Lau W, Hassel W, Gunreben G, Mertens HG, Brawanski A. Continuous-Pressure Controlled, External Ventricular Drainage for Treatment of Acute HydrocephalusEvaluation of Risk Factors. Neurosurgery 1992; 31: 898-904. [CrossRef]

11. Macmahon P, Cooke RWI. Hyponatraemia caused by repeated cerebrospinal fluid drainage in posthaemorrhagic hydrocephalus. Arch Dis Child 1983; 58: 385-6. [CrossRef]

12. Phi JH, Shin CH, Wang KC, Park SH, Kim SK. Catastrophic electrolyte imbalance caused by excessive production and overdrainage of cerebrospinal fluid in an infant with choroid plexus papilloma. Childs Nerv Syst 2011; 27: 1153-6. [CrossRef]

13. Saito A, Nishimura S, Fujita T, Sasaki T, Nishijima M. A case of difficult management of fluid-electrolyte imbalance in choroid plexus papilloma. Neurol Med Chir (Tokyo) 2014; 54: 659-63. [CrossRef]

14. Simpson S, Yung M, Slater A. Severe Dehydration and Acute Renal Failure Associated with External Ventricular Drainage of Cerebrospinal Fluid in Children. Anaesth Intensive Care 2006; 34: 659-63.

15. Tobias JD. Cerebrospinal fluid losses through ventricular catheters leading to hyponatremia in two children. South Med J 1991; 84: 279-80. [CrossRef]

16. Funk GC, Lindner G, Druml W, Metnitz B, Schwarz C, Bauer $\mathrm{P}$, et al. Incidence and prognosis of dysnatremias present on ICU admission. Intensive Care Med 2010; 36: 304-11. [CrossRef]

17. Ellis SJ. Severe hyponatraemia: complications and treatment. QJM 1995; 88: 905-909.

18. Sterns RH, Silver SM. Cerebral salt wasting versus SIADH: what difference? J Am Soc Nephrol 2008; 19: 194-6.

19. Hladky SB, Barrand MA. Mechanisms of fluid movement into, through and out of the brain: evaluation of the evidence. Fluids Barriers CNS 2014; 11: 26. [CrossRef]

20. Venkatesh B, Scott P, Ziegenfuss M. Cerebrospinal fluid in critical illness. Critical Care and Resuscitation 2000; 2: 42-54.

21. Robertson DS. The physical chemistry of brain and neural cell membranes: an overview. Neurochem Res 2010; 35: 681-7. [CrossRef]

22. Praetorius J. Water and solute secretion by the choroid plexus. Pflugers Arch 2007; 454: 1-18. [CrossRef] 